\title{
Correlated responses to selection for large body size in oMt1a-oGH transgenic mice: organ traits
}

\author{
K.R. Parks ${ }^{1}$, E.J. Eisen ${ }^{l}$ and J.D. Murray ${ }^{2}$
}

\begin{abstract}
The objective of the present study was to compare correlated responses in liver, spleen, kidney, heart and testis absolute weights and as a percentage of 8-week body weight following selection for large 8-week body weight in twice-replicated nontransgenic and transgenecarrier lines of mice from two genetic backgrounds. The transgene was an ovine metallothionein 1a-ovine growth hormone (oMt1a-oGH) construct, which was activated by adding $25 \mathrm{mM} \mathrm{ZnSO}_{4}$ to the drinking water. Lines $\mathrm{NM}$ and NC were nontransgenic lines derived from a high-growth and randomly selected background, respectively. Lines TM and TC were transgene-carrier lines formed from the respective genetic backgrounds. Line $\mathrm{CC}$ was a nontransgenic control from the randomly selected background. At weaning, male mice from each line were assigned to either zinc supplemented or control drinking water. Toe-clips were assayed by PCR for the presence or absence of the transgene. Correlated responses of absolute weights of all organs in nontransgenic lines indicated moderately high genetic correlations of organ weights with body weight, but on a percentage of body weight basis, the correlated responses were much lower. The correlated responses in visceral organ weights were lower in the presence of the inactivated oMt1a-oGH transgene than in its absence. The presence of the activated oMt1a-oGH combined with the effects of selection for growth increase had a greater impact on increasing the size of the splanchnic organs than did selection for large body weight in the absence of the transgene.
\end{abstract}

\section{INTRODUCTION}

A major selection criterion in meat-producing animals is increased lean growth rate (Mrode, 1988; Simm, 1992; Clutter and Brascamp, 1998). Lean growth and closely associated traits are assumed to be under polygenic control. The advent of transgene technology may make it possible to introduce into livestock a regulated major transgene, e.g., the structural gene for growth hormone (GH) or insulin-like growth factor I (IGF-I), having a large positive effect on lean growth (Pinkert and Murray, 1999; Pursel et al., 1999). The feasibility of combining conventional selection with a GH transgene has been explored with several mouse models (Nagai et al., 1993; Siewerdt et al., 1999, 2000).

Data on correlated responses in the growth of internal organs following selection for growth and/or the incorporation of a transgene affecting growth are of value in understanding the quantitative genetics of growth and development (Eisen, 1986). The magnitude of these changes on specific organ weights may affect such diverse biological functions as protein synthesis, maintenance requirements and reproduction. Fractional rates of protein synthesis are higher in visceral organs than in skeletal muscle (Garlick et al., 1976). Internal organs contribute more to maintenance requirements than skeletal muscle (Tess et al., 1984). Size of reproductive organs may impact reproduc- tive function (Eisen and Johnson, 1981). Correlated responses to selection for growth have been reported for various organ traits of mice (Robinson and Bradford, 1969; Eisen et al., 1978; Falconer et al., 1978; Eisen and Johnson, 1981; Eisen, 1986), as has the influence of a GH transgene on organ traits (Shea et al., 1987; Brem and Wanke, 1988; Brem et al., 1989; Pomp et al., 1992; Cecim et al., 1993). The present study focuses on correlated changes in organ traits when selection for increased body weight was conducted in the presence of a regulated $\mathrm{GH}$ transgene (Siewerdt et al., 1999, 2000).

\section{MATERIAL AND METHODS}

Source of stocks

The selected lines were formed with the objective of determining how selection response for increased growth would be affected by 1) the presence versus absence of a GH transgene, 2) a high-growth versus a randomly selected background, and 3) interaction between the two factors (Siewerdt et al., 1999, 2000). The ovine metallothionein la-ovine growth hormone (oMt1a-oGH) fusion gene (Shanahan et al., 1989) was backcrossed into a high-growth (M16) and randomly selected line (ICR). The M16 line had undergone long-term selection for 3- to 6-week postweaning weight gain, initiated from the ICR base (Eisen, 1975).

\footnotetext{
${ }^{1}$ Department of Animal Science, Box 7621, North Carolina State University, Raleigh, NC 27695, USA. Send correspondence to E.J.E. Fax: +1-919-515-7780. E-mail: gene_eisen@ncsu.edu

${ }^{2}$ Department of Animal Science and Department of Population Health and Reproduction, University of California, Davis, CA 95616, USA. Fax: +1-530-752-0175. E-mail: jdmurray@ucdavis.edu
} 
An advantage of the oMt1a-oGH construct over other GH transgene models is that the transgene can be regulated by the addition and withdrawal of supplementary zinc in the drinking water (Shanahan et al., 1989).

After backcrossing of the transgene into the M16 and ICR lines, within-full-sib-family selection for increased 8-week body weight was conducted in four lines (Siewerdt et al., 1999). Lines NM and NC were nontransgenic lines derived from the high-growth and randomly selected backgrounds, respectively. Lines TM and TC were transgenecarrier lines formed from these respective genetic backgrounds. A nontransgenic control line (CC) derived from the randomly selected background was maintained contemporaneously with the weight-selected lines. All lines were temporally replicated twice. The initial frequency of the transgene was 0.5 in TM and TC, but the frequency declined markedly in TM and rose moderately in TC over the course of selection (Siewerdt et al., 1999). In each generation of selection, all mice received $25 \mathrm{mM} \mathrm{ZnSO}_{4}$ in deionized drinking water between 3 and 8 weeks of age.

\section{Experimental design}

The experimental design was described by Parks et al. (2000a,b). Briefly, male mice were sampled from replicate 1 in generation 7 and replicate 2 in generation 8 of the selection study. Litters were standardized to eight pups. The approximate numbers of litters per line and male mice per line were 24 and 80 , respectively. Toe-clips from pups in line $\mathrm{TM}$ and $\mathrm{TC}$ were frozen at $-20^{\circ} \mathrm{C}$ for later polymerase chain reaction assay of DNA to determine the carriers of the oMt1a-oGH transgene (Pomp and Murray, 1991). The genotypes were not identified until all the data were collected.

Males were weaned and caged individually at 3 weeks of age, at which time mice were randomly assigned within litters to receive either $25 \mathrm{mM} \mathrm{ZnSO}_{4}$ in deionized drinking water (Z) or plain tap water (C). At 8 weeks of age, mice were weighed, killed by cervical dislocation, and the following organs were dissected and wet weights recorded: liver, spleen, right kidney, heart and right testis.

Mice were provided free access to feed and water. Purina Mouse Chow 5015 (Purina Mills, St. Louis, MO, USA) containing 102 ppm zinc was available to dams during mating, gestation and lactation. Purina Lab Chow 5001 (Purina Mills) containing $70 \mathrm{ppm}$ zinc was fed from 3 to 8 weeks of age. Temperature $\left(22^{\circ} \mathrm{C}\right)$, humidity $(55 \%)$ and light cycle (12-h light:12-h dark) were maintained in the laboratory.

\section{Statistical analysis}

Organ traits were analyzed on an absolute weight basis, as a percentage of 8-week body weight and as the logarithm of organ weight adjusted by covariance analysis for the logarithm of body weight. The latter two analyses led to similar conclusions, so that only the percentage data are presented. Organ traits were subjected to two mixed model analyses of variance using PROC MIXED in SAS ${ }^{\circledR}$ (Littell et al., 1996).

The first model contained the fixed effects of replicate-generation, line, treatment $(\mathrm{Z}$ versus $\mathrm{C})$ and line by treatment interaction, and the random effects of litter nested within line by replicate-generation subclass and residual. Orthogonal contrasts were partitioned as follows: $\mathrm{s}$, high-growth (NM and TM) versus control (NC and TC) background lines; $t$, transgene-carrier (TM and TC) versus nontransgenic (NM and NC) lines; $\mathrm{s} x \mathrm{t}$, selection background by transgenic line interaction; overall, selected lines (NM, $\mathrm{TM}, \mathrm{NC}$ and TC) versus the unselected control line (CC); trt, (Z versus $\mathrm{C})$; s $x$ trt, $\mathrm{t} x$ trt, $\mathrm{s} x \mathrm{t} x$ trt and overall $\mathrm{x}$ trt, the respective interaction with treatment effects. Four non-orthogonal contrasts were used to test for correlated responses in the $\mathrm{NC}$ and TC lines by taking deviations from the $\mathrm{CC}$ line within $\mathrm{Z}$ and $\mathrm{C}$ treatments, respectively. It was not possible to make analogous comparisons with NM and TM because there was no control line in the high-growth background.

The second mixed model involved only the transgenecarrier lines, TM and TC. The relevant fixed effects, expressed as orthogonal contrasts, were: line, (TM versus TC); $\mathrm{Q}$, transgenic $(\mathrm{T})$ versus nontransgenic $(\mathrm{N})$ mice; trt, $(\mathrm{Z}$ versus $\mathrm{C}$ ), and all possible interactions.

\section{RESULTS}

\section{Line by treatment effects}

Line by treatment means for each organ on an absolute weight and as a percentage of 8-week body weight basis are listed in Tables I and II, respectively, and corresponding orthogonal contrasts are given in Tables III and IV. On an absolute weight and percentage of body weight basis, line effects were highly significant for all organs (Tables I and II) and zinc-supplemented mice had larger $(\mathrm{P}<0.001)$ kidneys and smaller $(\mathrm{P}<0.05)$ testis than nonsupplemented mice (Tables III and IV). However, line by treatment interactions were present for absolute and percentage weights of liver, spleen and kidney $(\mathrm{P}<0.001)$, heart weight $(\mathrm{P}<$ $0.05)$ and testis percentage $(\mathrm{P}<0.05)$.

Considering the line orthogonal contrasts (Tables III and IV), high-growth background lines had significantly larger livers and spleens on a weight and percentage basis than lines from the randomly selected background. Genetic background effects (s) for kidney, heart and testis depended on how these organ traits were expressed; high-growth lines were significantly larger on a weight basis, but were significantly smaller on a percentage basis. Transgene-carrier lines had a larger $(\mathrm{P}<0.001)$ liver percentage than nontransgenic lines $(\mathrm{t})$, but there was no difference for absolute weight. There were, however, genetic background by transgenic line interactions ( $\mathrm{s} x \mathrm{t}$ ) for spleen weight (TM $\mathrm{NM}=-20 \pm 8.3 \mathrm{mg}, \mathrm{P}\langle 0.05$ vs. $\mathrm{TC}-\mathrm{NC}=13 \pm 8.3, \mathrm{P}\rangle$ 
Table I - Least-squares means and SE for line by treatment subclasses and ANOVA significance levels of absolute 8-week organ weights (mg).

\begin{tabular}{|lrrrrrr|}
\hline $\begin{array}{l}\text { Line }^{\mathrm{a}} \text { x } \\
\text { Treatment }^{\mathrm{b}}\end{array}$ & $\mathrm{N}$ & Liver & Spleen & Kidney & Heart & Testis \\
\hline CC x C & 42 & 1,905 & 80 & 311 & 206 & 99 \\
CC x Z & 41 & 1,695 & 70 & 303 & 202 & 94 \\
NC x C & 43 & 2,382 & 111 & 385 & 239 & 114 \\
NC x Z & 42 & 2,196 & 99 & 414 & 241 & 112 \\
NM x C & 43 & 3,574 & 205 & 429 & 311 & 122 \\
NM x Z & 41 & 3,221 & 173 & 436 & 293 & 121 \\
TC x C & 36 & 1,976 & 91 & 285 & 223 & 113 \\
TC x Z & 34 & 2,822 & 145 & 469 & 255 & 111 \\
TM x C & 43 & 3,259 & 178 & 403 & 292 & 119 \\
TM x Z & 40 & 3,270 & 160 & 450 & 289 & 110 \\
Pooled SE & & 92 & 7 & 14 & 9 & 3 \\
Line & & $* * *$ & $* * *$ & $* * *$ & $* * *$ & $* * *$ \\
Treatment & & NS & NS & $* * *$ & NS & $*$ \\
Line x Treatment & $* * *$ & $* * *$ & $* * *$ & $*$ & NS \\
\hline
\end{tabular}

${ }^{\mathrm{a}} \mathrm{CC}$, Randomly selected control; the following lines were selected for large 8-week body weight: NC, nontransgenic line from control background; NM, nontransgenic line from high-growth background; TC, transgene-carrier line from control background; TM, transgene-carrier line from high-growth background. ${ }^{\mathrm{b}} \mathrm{Z}$, Zinc supplementation; $\mathrm{C}$, no supplementation. ${ }^{\mathrm{C} N S}$, F-test not significant $(\mathrm{P}>0.05)$. $* \mathrm{P}<0.05$, $* * * \mathrm{P}<$ 0.001 .

Table II - Least-squares means and SE for line by treatment subclasses and ANOVA significance levels of organ weights as a percentage of 8 -week body weight $(\%)$.

\begin{tabular}{|lcccccc|}
\hline $\begin{array}{l}\text { Line x } \\
\text { Treatment }\end{array}$ & $\mathrm{N}$ & Liver & Spleen & Kidney & Heart & Testis \\
\hline CC x C & 42 & 6.12 & 0.26 & 1.00 & 0.66 & 0.32 \\
CC x Z & 41 & 5.71 & 0.24 & 1.02 & 0.68 & 0.32 \\
NC x C & 43 & 6.50 & 0.31 & 1.05 & 0.65 & 0.31 \\
NC x Z & 42 & 5.98 & 0.27 & 1.13 & 0.66 & 0.31 \\
NM x C & 43 & 7.11 & 0.41 & 0.86 & 0.62 & 0.25 \\
NM x Z & 41 & 6.40 & 0.34 & 0.87 & 0.59 & 0.24 \\
TC x C & 36 & 6.15 & 0.28 & 0.89 & 0.69 & 0.36 \\
TC x Z & 34 & 7.62 & 0.39 & 1.26 & 0.70 & 0.31 \\
TM x C & 42 & 6.87 & 0.38 & 0.85 & 0.63 & 0.26 \\
TM x Z & 39 & 6.98 & 0.34 & 0.97 & 0.62 & 0.24 \\
Pooled SE & & 0.15 & 0.017 & 0.025 & 0.022 & 0.009 \\
Line & & $* * *$ & $* * *$ & $* * *$ & $* *$ & $* * *$ \\
Treatment & NS ${ }^{\mathrm{b}}$ & NS & $* * *$ & NS & $* *$ \\
Line x Treatment & $* * *$ & $* * *$ & $* * *$ & NS & $*$ \\
\hline
\end{tabular}

${ }^{a}$ See Table I for description of lines and treatments. ${ }^{b} \mathrm{NS}$, F-test not significant $(\mathrm{P}>0.05)$. $* \mathrm{P}<0.05, * * \mathrm{P}<0.01, * * * \mathrm{P}<0.001$.

$0.05)$, liver percentage $(\mathrm{TM}-\mathrm{NM}=0.17 \pm 0.16 \%, \mathrm{P}>$ 0.05 vs. $\mathrm{TC}-\mathrm{NC}=0.64 \pm 0.16 \%, \mathrm{P}<0.001)$ and spleen percentage $(\mathrm{TM}-\mathrm{NM}=-0.014 \pm 0.018 \%, \mathrm{P}>0.05$ vs. TC - $\mathrm{NC}=0.047 \pm 0.018 \%, \mathrm{P}<0.01)$. Overall, the four selected lines had larger $(\mathrm{P}<0.001)$ absolute organ weights and proportionally larger $(\mathrm{P}<0.001)$ livers and spleens and smaller $(\mathrm{P}<0.001)$ testis than the $\mathrm{CC}$ control line.

Genetic background by treatment interactions (s x trt) were found for absolute and proportional weights of liver, spleen and kidney and for heart weight (Tables III and IV).
In the absence of zinc treatment, absolute and percentage weights of high growth exceeded control background lines for liver and spleen, respectively $(1,237 \pm 91 \mathrm{mg}, 91 \pm 7$ $\mathrm{mg}, 0.67 \pm 0.15 \%, 0.10 \pm 0.017 \%$; $\mathrm{P}<0.001)$, but when dietary zinc supplement was administered the differences were reduced for liver and spleen weights $(737 \pm 93 \mathrm{mg}$, $44 \pm 8 \mathrm{mg} ; \mathrm{P}<0.001)$ and were not significant for the respective percentages $(-0.11 \pm 0.16 \%, 0.013 \pm 0.017 \%$; $\mathrm{P}>$ $0.05)$. For the kidney, larger absolute weights were found in the high-growth background in the absence of zinc but not when zinc was added $(81 \pm 14 \mathrm{mg}$; $\mathrm{P}<0.001$ vs. $3 \pm 14$ $\mathrm{mg}, \mathrm{P}>0.05$ ), whereas smaller percentages were noted in the high-growth background, the difference being less with than without zinc supplement $(-0.11 \pm 0.025 \% ; \mathrm{P}<0.001$ vs. $-0.27 \pm 0.025 \%$; $P<0.001)$. The $\mathrm{s} x$ trt interaction for absolute heart weight occurred because the high-growth background lines had a greater difference than the random background lines without than with zinc added $(70 \pm 9 \mathrm{mg}$; $\mathrm{P}<0.001$ vs. $43 \pm 9 \mathrm{mg} ; \mathrm{P}<0.001)$.

Transgenic line by treatment ( $\mathrm{x}$ trt) interactions ( $\mathrm{P}$ $<0.001)$ for absolute and percentage weights of liver, spleen and kidney occurred because these organs were significantly larger in transgene-carrier lines than in nontransgenic lines when supplemented with zinc $(338 \pm 93$ $\mathrm{mg}, \mathrm{P}<0.001 ; 16 \pm 8 \mathrm{mg}, \mathrm{P}<0.05 ; 34 \pm 14 \mathrm{mg}, \mathrm{P}<0.05$, $1.11 \pm 0.16 \%, 0.60 \pm 0.017 \%, 0.11 \pm 0.025 \%, P<0.001$ ), but the differences were reversed when zinc was withheld $(-360 \pm 91 \mathrm{mg},-24 \pm 7 \mathrm{mg},-63 \pm 14 \mathrm{mg}, \mathrm{P}<0.001 ;-0.30$ $\pm 0.14 \%, \mathrm{P}<0.05 ;-0.026 \pm 0.017 \%, \mathrm{P}>0.05 ;-0.083 \pm$ $0.025 \%, \mathrm{P}<0.001)$. A similar directional $\mathrm{t} x$ trt interaction occurred for heart weight $(5 \pm 9 \mathrm{mg}, \mathrm{P}>0.05$ vs. $-18 \pm$ $9 \mathrm{mg}, \mathrm{P}<0.05)$. The $\mathrm{x}$ trt interaction for testis percentage $(\mathrm{P}<0.01)$ was due to a nonsignificant difference between transgene-carrier and nontransgenic lines with zinc, whereas the transgene-carrier lines had larger testis percentage when zinc was added.

\section{Correlated responses in NC and TC lines}

The positive correlated responses in all five absolute organ weights of line $\mathrm{NC}$ were significant and of similar magnitude with or without the addition of zinc to the drinking water (Figure 1). When expressed as a percentage of body weight, the only significant correlated responses were positive values for spleen without zinc supplement and kidney with zinc supplement (Figure 2). In line TC, positive correlated responses $(\mathrm{P}<0.001)$ in all five absolute organ weights were found when zinc was added, but only testis weight showed a positive correlated response $(\mathrm{P}<0.01)$ with no zinc supplement (Figure 1). On a percentage basis, positive correlated responses were obtained for liver and testis and a negative correlated response for kidney in the absence of zinc supplement (Figure 2). When zinc was provided as a supplement, positive correlated responses were found for liver, spleen and kidney as a percentage of body weight. 
Table III - Orthogonal contrasts \pm SE involving

NC, NM, TC, TM and CC lines ${ }^{\mathrm{a}}$ for absolute 8-week organ weights (mg).

\begin{tabular}{|c|c|c|c|c|c|}
\hline Contrast & Liver & Spleen & Kidney & Heart & Testis \\
\hline $\mathrm{s}^{\mathrm{b}}$ & $1,974 \pm 150^{* * *}$ & $135 \pm 12 * * *$ & $83 \pm 23 * * *$ & $113 \pm 15^{* * * *}$ & $11 \pm 5^{*}$ \\
\hline$t^{\mathrm{c}}$ & $23 \pm 150$ & $-8 \pm 12$ & $-29 \pm 23$ & $-12 \pm 15$ & $-8 \pm 5$ \\
\hline trt & $22 \pm 47$ & $-4 \pm 4$ & $52 \pm 7 * * *$ & $2 \pm 5$ & $-4 \pm 2 *$ \\
\hline $\mathrm{s} \times \mathrm{t}^{\mathrm{e}}$ & $-243 \pm 150$ & $-33 \pm 12 * *$ & $17 \pm 23$ & $-10 \pm 15$ & $-6 \pm 5$ \\
\hline Overall $^{\mathrm{f}}$ & $4,150 \pm 328 * * *$ & $280 \pm 26^{* * *}$ & $407 \pm 50^{* * *}$ & $255 \pm 33^{* * * *}$ & $76 \pm 12 * * *$ \\
\hline $\mathrm{sx} \operatorname{trt}^{\mathrm{g}}$ & $-1,001 \pm 213^{* * *}$ & $-93 \pm 18 * * *$ & $-159 \pm 31 * * *$ & $-54 \pm 22 * *$ & $-5 \pm 7$ \\
\hline $\mathrm{t} x \operatorname{trt}^{\mathrm{h}}$ & $1,396 \pm 213^{* * *}$ & $80 \pm 18 * * *$ & $193 \pm 31 * * *$ & $45 \pm 22 *$ & $-10 \pm 7$ \\
\hline$(\mathrm{s} \times \mathrm{t}) \times \operatorname{trt}^{\mathrm{i}}$ & $-668 \pm 213^{* *}$ & $-51 \pm 18 * *$ & $-115 \pm 31 * * *$ & $-14 \pm 22$ & $-9 \pm 7$ \\
\hline Overall $\mathrm{x} \operatorname{tr} \mathrm{t}^{\mathrm{j}}$ & $1,158 \pm 470 *$ & $30 \pm 40$ & $300 \pm 69 * * *$ & $28 \pm 49$ & $5 \pm 16$ \\
\hline
\end{tabular}

${ }^{a}$ See Table I for description of lines. ${ }^{\mathrm{b}} \mathrm{High}$-growth background lines versus control background lines. Contrast is NM

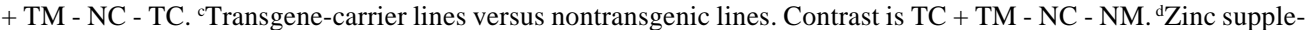
mentation versus no supplementation. Contrast is $\mathrm{Z}-\mathrm{C}$. ${ }^{\mathrm{e}}$ Contrast is NC + TM - NM -TC. ${ }^{\mathrm{f}}$ Contrast is NC + NM + TC $+\mathrm{TM}-4 \mathrm{CC} .{ }^{\mathrm{g}}$ Contrast is $(\mathrm{NC} \times \mathrm{C})+(\mathrm{NM} \times \mathrm{Z})+(\mathrm{TC} \times \mathrm{C})+(\mathrm{TM} \times \mathrm{Z})-(\mathrm{NC} \times \mathrm{Z})-(\mathrm{NM} \times \mathrm{C})-(\mathrm{TC} \times \mathrm{Z})-(\mathrm{TM} \times \mathrm{C}) .{ }^{\mathrm{h}} \mathrm{Contrast}$ is $(N C \times C)+(N M x C)+(T C x Z)+(T M x Z)-(N C x Z)-(N M x Z)-(T C x C)-(T M x C) .{ }^{i}$ Contrast is $(N C x Z)+(N M x$ $\mathrm{C})+(\mathrm{TC} \times \mathrm{C})+(\mathrm{TM} \times \mathrm{Z})-(\mathrm{NC} \times \mathrm{C})-(\mathrm{NM} \times \mathrm{Z})-(\mathrm{TC} \times \mathrm{Z})-(\mathrm{TM} \times \mathrm{C}) .{ }^{\mathrm{j}}$ Contrast is $4(\mathrm{CC} \times \mathrm{C})+(\mathrm{NC} \times \mathrm{Z})+(\mathrm{NM} \times \mathrm{Z})+(\mathrm{TC}$ $\mathrm{x} Z)-4(\mathrm{CC} \times \mathrm{Z})-(\mathrm{NM} \times \mathrm{C})-(\mathrm{TC} \times \mathrm{C})-(\mathrm{TM} \times \mathrm{C})$. $* \mathrm{P}<0.05$, **P $<0.01, * * * \mathrm{P}<0.001$.

Table IV - Orthogonal contrasts \pm SE involving

$\mathrm{NC}, \mathrm{NM}, \mathrm{TC}, \mathrm{TM}$ and CC lines ${ }^{\mathrm{a}}$ for organ weights as a percentage of 8-week body weight (\%).

\begin{tabular}{|c|c|c|c|c|c|}
\hline Contrast $\mathrm{t}^{\mathrm{b}}$ & Liver & Spleen & Kidney & Heart & Testis \\
\hline s & $0.56 \pm 0.23^{*}$ & $0.12 \pm 0.03^{* * *}$ & $0.38 \pm 0.04 * * *$ & $-0.12 \pm 0.04 * * *$ & $-0.15 \pm 0.02 * * *$ \\
\hline $\mathrm{t}$ & $0.82 \pm 0.23 * * *$ & $0.03 \pm 0.03$ & $0.03 \pm 0.04$ & $0.06 \pm 0.04$ & $0.02 \pm 0.02$ \\
\hline trt & $-0.01 \pm 0.08$ & $-0.01 \pm 0.01$ & $0.12 \pm 0.01 * * *$ & $-0.00 \pm 0.01$ & $-0.02 \pm 0.01 * *$ \\
\hline $\mathrm{sxt}$ & $-0.47 \pm 0.23 *$ & $-0.06 \pm 0.03 *$ & $0.04 \pm 0.04$ & $-0.02 \pm 0.04$ & $-0.01 \pm 0.02$ \\
\hline Overall & $3.16 \pm 0.51 * * *$ & $0.38 \pm 0.06^{* * *}$ & $-0.11 \pm 0.09$ & $-0.12 \pm 0.08$ & $-0.14 \pm 0.03 * * *$ \\
\hline $\mathrm{s} \times \mathrm{trt}$ & $-1.54 \pm 0.36^{* * * *}$ & $-0.18 \pm 0.04 * * *$ & $-0.32 \pm 0.06 * * *$ & $-0.05 \pm 0.05$ & $0.04 \pm 0.02$ \\
\hline $\mathrm{t} x \operatorname{trt}$ & $2.80 \pm 0.36^{* * * *}$ & $0.17 \pm 0.04 * * *$ & $0.39 \pm 0.06^{* * * *}$ & $0.03 \pm 0.05$ & $-0.06 \pm 0.02 * *$ \\
\hline$(\mathrm{s} \times \mathrm{t}) \times \operatorname{trt}$ & $-1.15 \pm 0.36^{* *}$ & $-0.12 \pm 0.04 * *$ & $-0.19 \pm 0.06 * *$ & $0.02 \pm 0.05$ & $0.03 \pm 0.02$ \\
\hline Overall $\mathrm{x}$ trt & $1.98 \pm 0.80^{*}$ & $0.04 \pm 0.09$ & $0.50 \pm 0.14 * * *$ & $-0.11 \pm 0.12$ & $-0.06 \pm 0.05$ \\
\hline
\end{tabular}

${ }^{a}$ See Table I for description of lines. ${ }^{b}$ See Table III for definition of contrasts. $* \mathrm{P}<0.05$. ** $\mathrm{P}<0.01, * * * \mathrm{P}<0.001$.

Transgene-carrier line by treatment by transgene effects

Transgene-carrier line (TC, TM) by treatment (C, Z) by transgene $(\mathrm{N}, \mathrm{T})$ means for absolute and percentage of body weight organ means are presented in Tables V and VI and corresponding orthogonal contrasts are in Tables VII and VIII. The small proportions of nontransgenic TC and transgenic TM mice are representative of the oMt 1a-oGH gene frequency in the generations of selection that were sampled (Siewerdt et al., 1999).

Line TM had significantly larger liver and spleen weights on an absolute and percentage of body weight basis and smaller kidney, heart and testis weights on a percentage basis compared with line TC. Transgenic mice had significantly larger liver, spleen and testis weights as a percentage of 8-week body weight and a smaller $(\mathrm{P}<0.05)$ heart weight than nontransgenic mice. Zinc supplemented mice had significantly larger liver, spleen and kidney organs when expressed on an absolute or percentage basis relative to nonsupplemented mice. No significant line by treatment in- teractions were found for any organ size traits. Line by transgene interactions were present for absolute weights of liver $(\mathrm{P}<0.01)$ and kidney $(\mathrm{P}<0.05)$. In the case of liver weight, TC transgenic mice exceeded nontransgenic mice (372 $\pm 171 \mathrm{mg}, \mathrm{P}<0.05$ ), but TM transgenic mice were smaller than TC transgenic mice $(-351 \pm 212 \mathrm{mg}, \mathrm{P}<0.10)$. Kidney weights of TC transgenic and nontransgenic mice were not different $(-30 \pm 31, \mathrm{P}>0.05)$, whereas TM transgenic mice had smaller kidney weights than TM nontransgenics $(-73 \pm 36, P<0.10)$. Significant treatment by transgene interactions were apparent for liver, spleen and kidney on a weight and proportion of body weight basis. The addition of zinc led to larger organ weights on a percentage scale in transgenic than in nontransgenic mice $(1.39 \pm 0.27 \%$, $\mathrm{P}<0.001$ for liver; $0.13 \pm 0.04 \%, \mathrm{P}<0.01$ for spleen, and $0.16 \pm 0.07 \%, \mathrm{P}<0.05$ for kidney), whereas in the absence of zinc, there were no significant differences between transgenic and nontransgenic mice for liver $(-0.08 \pm 0.23 \%$, $\mathrm{P}>0.05)$ and spleen $(-0.01 \pm 0.03 \%, \mathrm{P}>0.05)$ and transgenic mice had smaller kidneys $(-0.13 \pm 0.06 \%, P<0.05)$. Similar trends were noted on an absolute weight scale. 


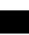

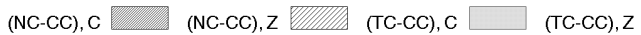

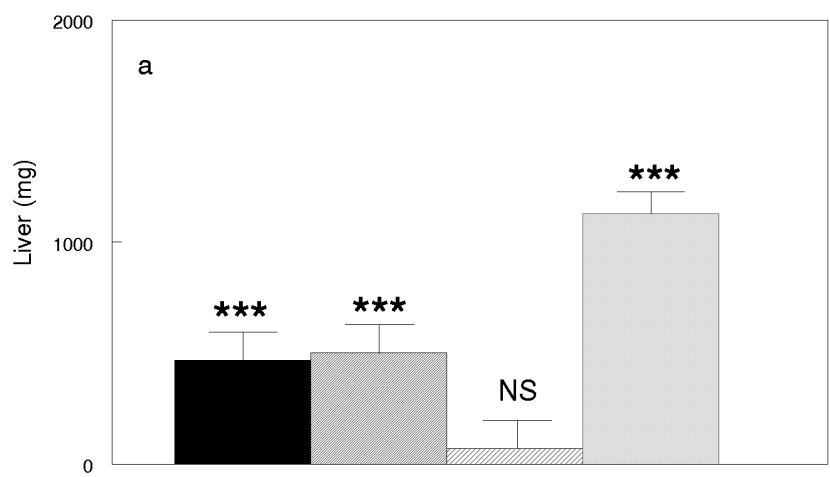

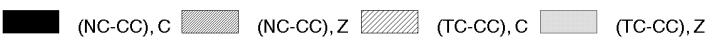

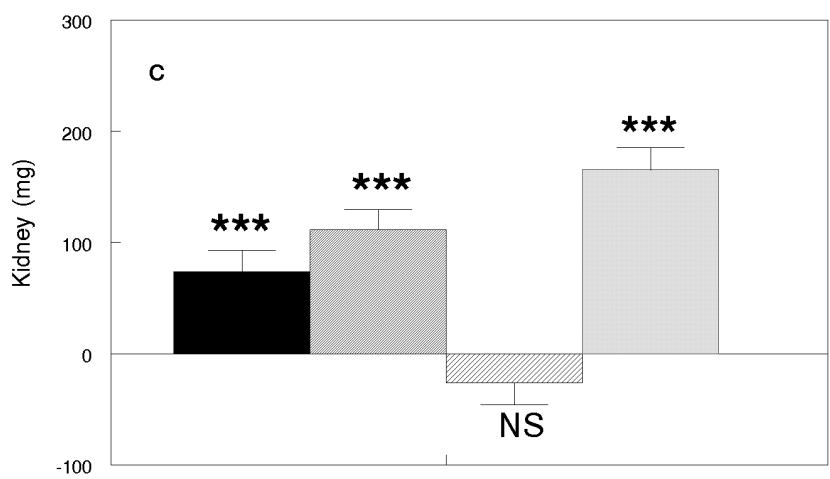

(NC-CC), $\mathrm{C}$ (NC-CC), Z Wrill (TC-CC), $\square$ (TC-CC), Z

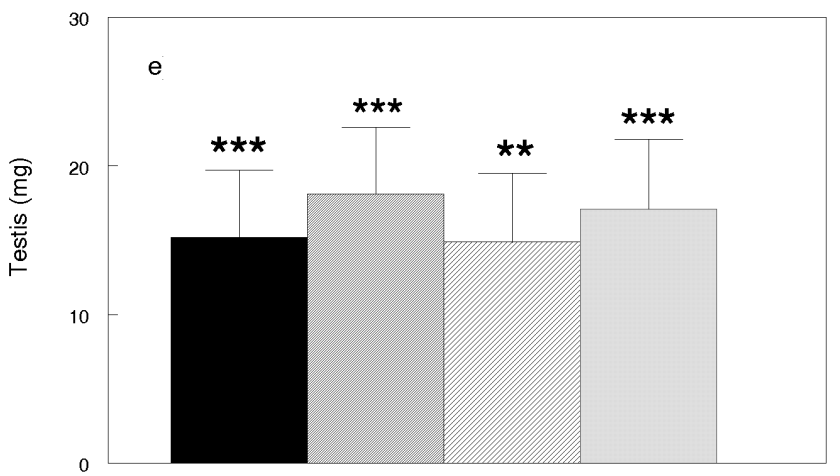

Activated transgene plus selection versus selection

To compare the combined effects on organ size of the activated GH transgene and selection for large 8-week body weight with selection for body weight alone, the pertinent means in the randomly selected background are TC $x \mathrm{Z} \times \mathrm{T}$ (Tables V and VI) and NC x Z (Tables I and II). The TC $x$ Z x T means exceeded $(P<0.001) ~ N C \times Z$ for liver, spleen and kidney on both an absolute and percentage basis while heart and testis contrasts were not significantly dif-
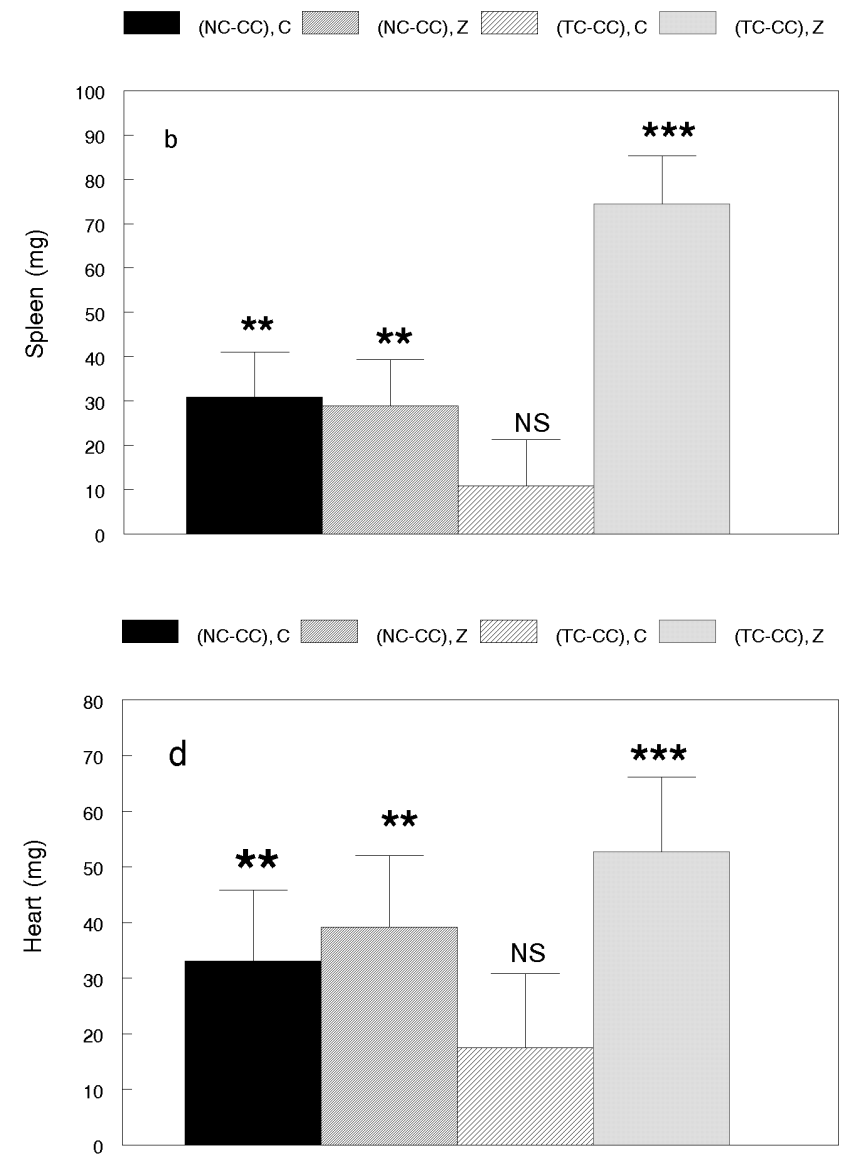

Figure 1 - Correlated responses for absolute organ weights (mg) in the NC and TC lines with $(\mathrm{Z})$ and without $(\mathrm{C})$ zinc supplementation expressed as deviations from the means of $\mathrm{CC}$, the randomly selected control line: a) liver, b) spleen, c) kidney, d) heart, e) testis. NC and TC are nontransgenic and transgene-carrier lines, respectively, originating from the same background as CC, and subsequently selected for 8 -week body weight. NS = Not significant, $* * \mathrm{P}<0.01$, $* * * \mathrm{P}<0.001$.

ferent (Table IX). Analogous comparisons were not made in the high-growth background because only four mice were available in the $\mathrm{TM} \times \mathrm{Z} \times \mathrm{T}$ group.

\section{DISCUSSION}

\section{Correlated responses in a nontransgenic line}

The nontransgenic NC line had positive correlated responses in absolute weights of liver, spleen, kidney, heart and testis following selection for large 8-week body weight, 


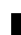

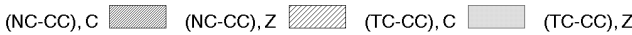

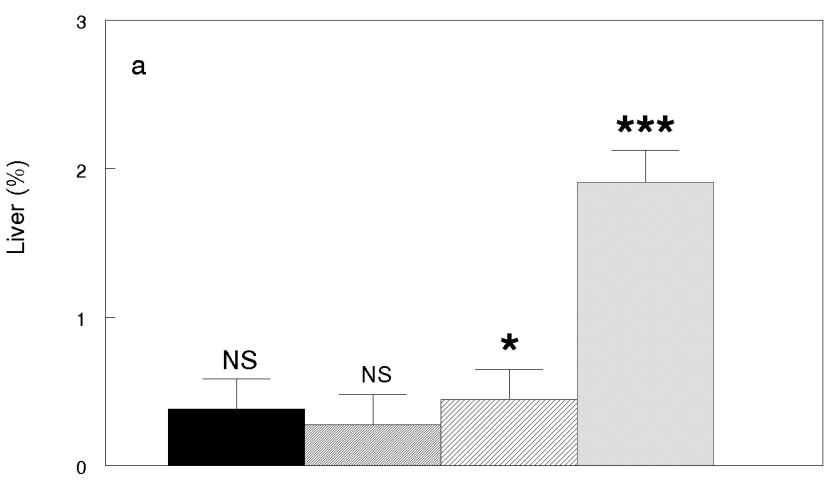

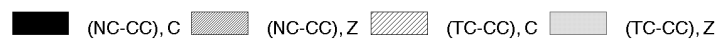

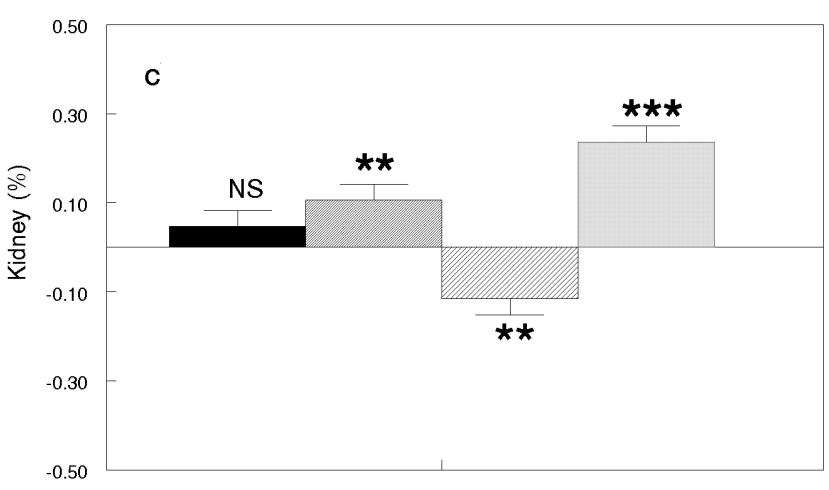

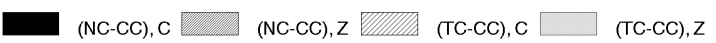

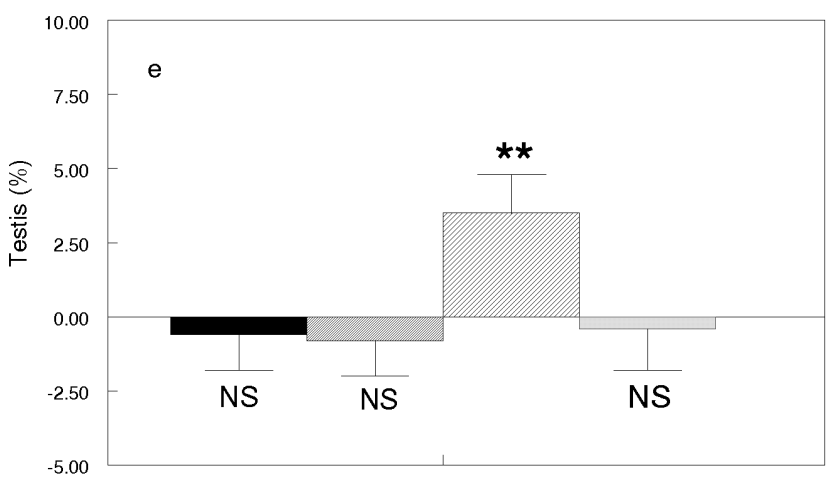

the zinc supplement having had no effect on the correlated responses for each organ. Positive correlated responses in liver, spleen, kidney and heart weights have been observed previously in lines selected for large body weight (Nash and Logsdon, 1978; Bünger et al., 1985). The correlated responses are in agreement with moderately high positive genetic correlations of these respective organ weights with adult body weight (Eisen and Johnson, 1981; Kramer et al., 1998). The absence of a zinc effect on correlated responses in organ weights indi-
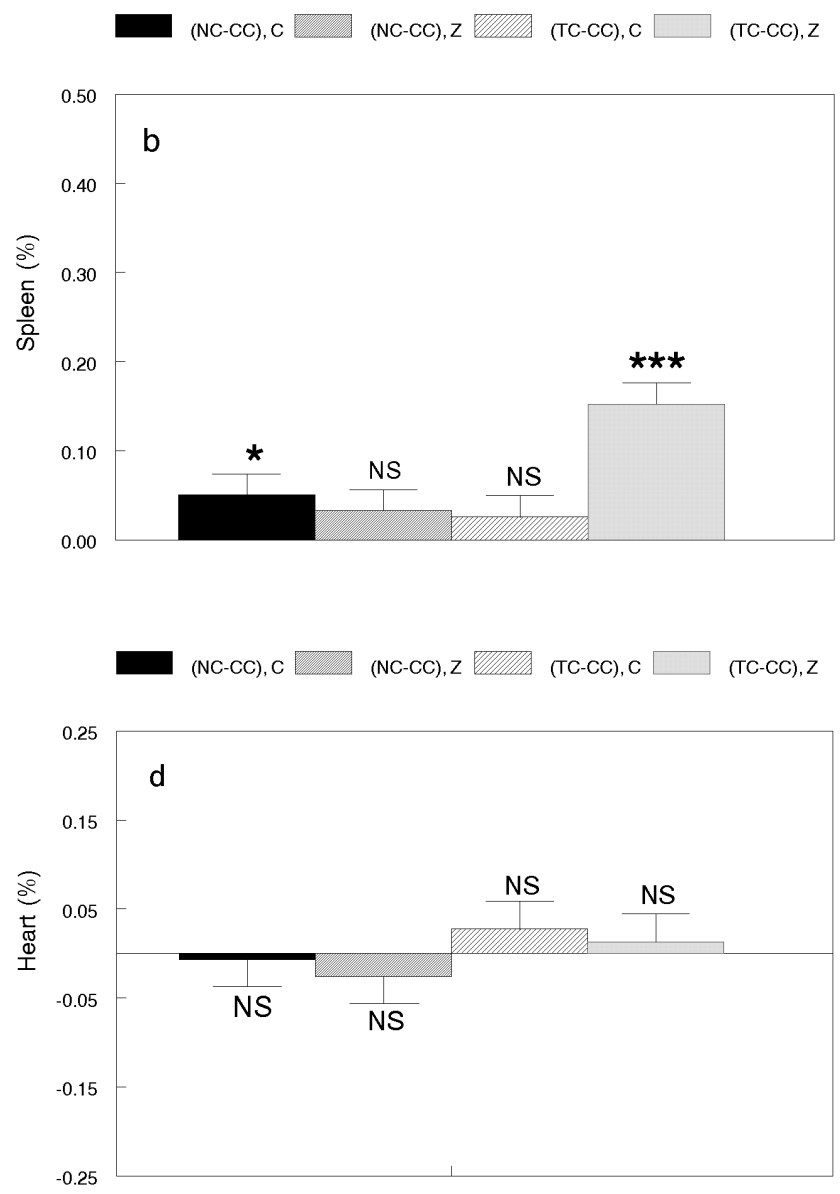

Figure 2 - Correlated responses for organ weights as a percentage of 8week body weight in the NC and TC lines with (Z) and without (C) zinc supplementation expressed as deviations from the means of $\mathrm{CC}$, the randomly selected control line: a) liver, b) spleen, c) kidney, d) heart, e) testis. $\mathrm{NC}$ and TC are nontransgenic and transgene-carrier lines, respectively, originating from the same background as $\mathrm{CC}$, and subsequently selected for 8 -week body weight. NS $=$ Not significant, $* \mathrm{P}<0.05$. ** $\mathrm{P}<0.01$, *** $\mathrm{P}$ $<0.001$.

cates that $25 \mathrm{mM} \mathrm{ZnSO}_{4}$ is not having any detrimental influences on organ growth as related to selection for overall body growth.

Rather than comparing lines at the same age, an alternative approach is to make comparisons at the same degree of maturity in body weight (Taylor, 1980). For degrees of maturity ranging from 37.5 to $100 \%$, lines selected for high postweaning gain had larger liver, spleen, kidney, heart and testis weights than a randomly selected control line (Eisen, 1986). Therefore, the genetic correla- 
Table V - Least-squares means \pm SE for line by treatment by transgene subclasses within lines TC and TM for absolute organ weights ( $\mathrm{mg}$ ).

\begin{tabular}{|lrlclll|}
\hline $\begin{array}{l}\text { Line x Treatment } \\
\text { x Transgene }^{\mathrm{b}}\end{array}$ & $\mathrm{N}$ & Liver & Spleen & Kidney & Heart & Testis \\
\hline TCx Cx N & 8 & $2,225 \pm 198$ & $100 \pm 17$ & $342 \pm 35$ & $254 \pm 21$ & $107 \pm 8$ \\
TCx Cx T & 28 & $1,992 \pm 107$ & $88 \pm 9$ & $270 \pm 19$ & $215 \pm 11$ & $115 \pm 5$ \\
TCx Zx N & 8 & $2,032 \pm 199$ & $99 \pm 17$ & $369 \pm 35$ & $243 \pm 21$ & $104 \pm 8$ \\
TCx Zx T & 26 & $3,080 \pm 111$ & $159 \pm 10$ & $500 \pm 20$ & $260 \pm 12$ & $112 \pm 5$ \\
TMx Cx N & 36 & $3,336 \pm 96$ & $182 \pm 8$ & $422 \pm 17$ & $302 \pm 10$ & $119 \pm 4$ \\
TMx Cx T & 7 & $2,880 \pm 221$ & $157 \pm 19$ & $305 \pm 40$ & $236 \pm 23$ & $120 \pm 9$ \\
TMx Zx N & 36 & $3,297 \pm 96$ & $157 \pm 8$ & $453 \pm 17$ & $294 \pm 10$ & $110 \pm 4$ \\
TMx Zx T & 4 & $3,051 \pm 291$ & $185 \pm 25$ & $425 \pm 52$ & $246 \pm 31$ & $102 \pm 12$ \\
\hline
\end{tabular}

${ }^{\mathrm{a} S e e}$ Table I for description of lines and treatments. ${ }^{\mathrm{b}} \mathrm{T}$, Transgene present; $\mathrm{N}$, transgene absent.

Table VI - Least-squares means \pm SE for line by treatment by transgene subclasses within lines TC and TM for organ weights as a percentage of 8 -week body weight (\%).

\begin{tabular}{|lrccccc|}
\hline $\begin{array}{l}\text { Line x Treatment } \\
\text { x Transgene }\end{array}$ & $\mathrm{N}$ & Liver & Spleen & Kidney & Heart & Testis \\
\hline TCx Cx N & 8 & $6.36 \pm 0.28$ & $0.29 \pm 0.039$ & $1.00 \pm 0.070$ & $0.74 \pm 0.050$ & $0.32 \pm 0.022$ \\
TCx Cx T & 28 & $6.12 \pm 0.15$ & $0.28 \pm 0.021$ & $0.86 \pm 0.038$ & $0.68 \pm 0.027$ & $0.37 \pm 0.012$ \\
TCx Zx N & 8 & $5.95 \pm 0.28$ & $0.29 \pm 0.039$ & $1.10 \pm 0.070$ & $0.72 \pm 0.050$ & $0.31 \pm 0.022$ \\
TCx Zx T & 26 & $8.14 \pm 0.16$ & $0.42 \pm 0.022$ & $1.31 \pm 0.040$ & $0.69 \pm 0.028$ & $0.30 \pm 0.012$ \\
TMx Cx N & 35 & $6.87 \pm 0.14$ & $0.38 \pm 0.020$ & $0.87 \pm 0.035$ & $0.64 \pm 0.024$ & $0.25 \pm 0.011$ \\
TMx Cx T & 7 & $6.96 \pm 0.31$ & $0.38 \pm 0.044$ & $0.75 \pm 0.078$ & $0.58 \pm 0.055$ & $0.30 \pm 0.025$ \\
TMx Zx N & 35 & $6.93 \pm 0.14$ & $0.33 \pm 0.019$ & $0.96 \pm 0.035$ & $0.62 \pm 0.024$ & $0.24 \pm 0.011$ \\
TMx Zx T & 4 & $7.52 \pm 0.41$ & $0.46 \pm 0.058$ & $1.07 \pm 0.103$ & $0.62 \pm 0.073$ & $0.26 \pm 0.032$ \\
\hline
\end{tabular}

${ }^{\mathrm{a} S e e}$ Table I for description of lines and treatments. ${ }^{\mathrm{b}} \mathrm{T}$, Transgene present; N, transgene absent.

Table VII - Orthogonal contrasts \pm SE within lines TC and $\mathrm{TM}^{\mathrm{a}}$ for absolute organ weights (mg).

\begin{tabular}{|c|c|c|c|c|c|}
\hline Contrast & Liver & Spleen & Kidney & Heart & Testis \\
\hline Line $^{b}$ & $826 \pm 138 * * *$ & $59 \pm 12 * * *$ & $31 \pm 25$ & $27 \pm 14$ & $3 \pm 6$ \\
\hline$Q^{c}$ & $11 \pm 130$ & $13 \pm 11$ & $-21 \pm 23$ & $-34 \pm 14 *$ & $2 \pm 6$ \\
\hline $\operatorname{Trt}^{\mathrm{d}}$ & $274 \pm 113^{*}$ & $18 \pm 10^{t}$ & $102 \pm 20^{* * *}$ & $9 \pm 12$ & $-8 \pm 5$ \\
\hline Line $x \operatorname{trt}^{\mathrm{e}}$ & $-416 \pm 227$ & $-33 \pm 19$ & $-53 \pm 41$ & $-16 \pm 24$ & $-10 \pm 9$ \\
\hline Line $x Q^{f}$ & $-723 \pm 272 * *$ & $-22 \pm 24$ & $-102 \pm 49 *$ & $-46 \pm 29$ & $-12 \pm 12$ \\
\hline Trt $x Q^{g}$ & $80 \pm 233 * * *$ & $62 \pm 20 * *$ & $146 \pm 42 * * *$ & $37 \pm 25$ & $-5 \pm 10$ \\
\hline Line $x \operatorname{trt} x Q^{h}$ & $-1,141 \pm 466^{*}$ & $-18 \pm 40$ & $-116 \pm 83$ & $-38 \pm 50$ & $-9 \pm 20$ \\
\hline
\end{tabular}

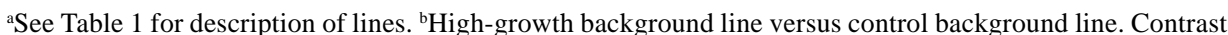
is TM - TC. ${ }^{c}$ Transgenic mice versus nontransgenic mice. Contrast is T - N. ${ }^{\mathrm{d}}$ Zinc supplementation versus no supplementation. Contrast is Z - C. ${ }^{e}$ Contrast is $(\mathrm{TC} \times \mathrm{C})+(\mathrm{TM} \times \mathrm{Z})-(\mathrm{TC} \times \mathrm{Z})-(\mathrm{TM} \times \mathrm{C}) .{ }^{\mathrm{f}}$ Contrast is $(\mathrm{TC} \times \mathrm{N})$ $+(\mathrm{TM} \times \mathrm{T})-(\mathrm{TC} \times \mathrm{T})-(\mathrm{TM} \times \mathrm{N}) .{ }^{\mathrm{g}} \mathrm{C}$ ontrast is $(\mathrm{C} \times \mathrm{N})+(\mathrm{Z} \times \mathrm{T})-(\mathrm{C} \times \mathrm{T})-(\mathrm{Z} \times \mathrm{N}) .{ }^{\mathrm{h}}$ Contrast is $(\mathrm{TC} \times \mathrm{C} \times \mathrm{T})+(\mathrm{TC}$ $x \mathrm{Z} \times \mathrm{N})+(\mathrm{TM} \times \mathrm{C} \times \mathrm{N})+(\mathrm{TM} \times \mathrm{Z} \times \mathrm{T})-(\mathrm{TC} \times \mathrm{C} \times \mathrm{N})-(\mathrm{TC} \times \mathrm{Z} \times \mathrm{T})-(\mathrm{TM} \times \mathrm{C} \times \mathrm{T})-(\mathrm{TM} \times \mathrm{Z} \times \mathrm{N}) \cdot{ }^{\mathrm{P}} \mathrm{P}<0.10, * \mathrm{P}<$ $0.05, * * \mathrm{P}<0.01, * * * \mathrm{P}<0.001$.

tions are as strongly positive on a degree of maturity basis as on an age basis.

When organ weights were analyzed as a percentage of 8-week body weight, only the spleen without zinc and the kidney with zinc had significant positive correlated responses in line NC. These data suggest that the genetic correlations between adult body weight and the respective organ weights as a percentage of body weight are lower than the corresponding genetic correlations between adult body weight and absolute organ weights. Because the genetic correlations of body weight with the respective organ weights as a percentage of body weight are part-whole correlations, the reason the genetic correlations between body weight and organ weight as a percentage of body weight are small can be explained in biometrical terms (Eisen, 1966). In this case, the difference between (the genetic coefficient of variation in the organ weight) times (the genetic correlation between the organ weight and body 
Table VIII - Orthogonal contrasts \pm SE within lines TC and TMa for organ weights as a percentage of 8-week body weight (\%).

\begin{tabular}{|c|c|c|c|c|c|}
\hline Contrast $^{\mathrm{b}}$ & Liver & Spleen & Kidney & Heart & Testis \\
\hline line & $0.43 \pm 0.18^{*}$ & $0.067 \pm 0.028^{*}$ & $-0.152 \pm 0.049^{* *}$ & $-0.092 \pm 0.034^{* *}$ & $-0.060 \pm 0.015^{* * * *}$ \\
\hline$Q$ & $0.66 \pm 0.18 * * *$ & $0.060 \pm 0.026^{*}$ & $0.016 \pm 0.046$ & $-0.035 \pm 0.032$ & $0.030 \pm 0.014 *$ \\
\hline Trt & $0.56 \pm 0.17 * *$ & $0.043 \pm 0.022 *$ & $0.239 \pm 0.040 * *$ & $0.005 \pm 0.029$ & $-0.030 \pm 0.013^{*}$ \\
\hline line $x$ trt & $-0.50 \pm 0.34$ & $-0.055 \pm 0.044$ & $-0.074 \pm 0.080$ & $0.018 \pm 0.058$ & $0.013 \pm 0.026$ \\
\hline line $\mathrm{x} Q$ & $-0.63 \pm 0.38$ & $0.008 \pm 0.054$ & $-0.037 \pm 0.096$ & $0.013 \pm 0.068$ & $0.013 \pm 0.030$ \\
\hline $\operatorname{trt} \times Q^{-}$ & $1.47 \pm 0.34 * * *$ & $0.137 \pm 0.045^{* *}$ & $0.298 \pm 0.082^{* *}$ & $0.048 \pm 0.060$ & $-0.040 \pm 0.026$ \\
\hline line $x \operatorname{trt} x Q$ & $-1.94 \pm 0.68 * *$ & $0.007 \pm 0.091$ & $-0.117 \pm 0.164$ & $0.036 \pm 0.119$ & $0.028 \pm 0.053$ \\
\hline
\end{tabular}

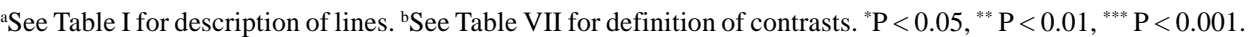

Table IX - Contrast of TC x Z x T with NC x Z organ means \pm SE on an absolute weight and percentage of body weight basis ${ }^{\mathrm{a}}$.

\begin{tabular}{|lcc|}
\hline Organ & Absolute weight $(\mathrm{mg})$ & Percentage of body weight $(\%)$ \\
\hline Liver & $884 \pm 144^{* * *}$ & $2.16 \pm 0.22^{* * * *}$ \\
Spleen & $60 \pm 12^{* * *}$ & $0.15 \pm 0.028 * * *$ \\
Kidney & $86 \pm 24^{* * *}$ & $0.18 \pm 0.047 * * *$ \\
Heart & $19 \pm 15$ & $0.03 \pm 0.039$ \\
Testis & $0 \pm 6$ & $-0.01 \pm 0.015$ \\
\hline
\end{tabular}

a See Table I for definition of lines; Z, zinc supplementation; T, transgene present. $* * * \mathrm{P}<0.001$

weight) and the genetic coefficient of variation in body weight must be small relative to the genetic standard deviation of the organ weight/body weight ratio.

\section{Correlated responses in a transgene-carrier line}

A major goal of the present study was to compare correlated responses in organ traits in the transgene-carrier $\mathrm{TC}$ line with those in the nontransgenic $\mathrm{NC}$ line. In the absence of zinc supplement, only absolute testis weight in the TC line showed a significant positive correlated response, indicating that the presence of the oMt1a-oGH transgene in the inactive state led to reduction in the genetic correlations between adult body weight and the respective weights of liver, spleen, kidney and heart. When the oMt 1a-oGH transgene was activated by addition of the zinc supplement, correlated responses in absolute organ weights were all positive, but these are probably overestimated because the control line used for TC did not contain the oMt 1 a-oGH transgene and liver, spleen, kidney and heart weights are known to be increased in GH-based transgenic mice (Pomp et al., 1992; Wanke et al., 1992; Eisen et al., 1995; Siewerdt et al., 1998). Therefore, a comparison was made between nontransgenic mice in TC and CC on the zinc supplemented diet; the correlated responses in these organs were positive but did not reach statistical significance.

Considering organ weights on a percentage of body weight basis, correlated responses in TC without zinc supplement were positive for liver and testis, and negative for kidney. With zinc supplement, the correlated responses were positive for liver, spleen and kidney, but again these are probably affected to a considerable extent by the absence of an unselected transgenic control line. There were no significant correlated responses in organ percentages when only nontransgenic TC mice were considered.

It is concluded that when selection was for adult body weight, the correlated responses in visceral organ weights were lower in the presence of the inactivated oMt1a-oGH transgene, while for testis weight the correlated response was probably not affected. Because selection was always conducted with the transgene activated (Siewerdt et al., 1999, 2000), when splanchnomegaly is common for GHbase transgenes (Wanke et al., 1992), it may be that genes affecting visceral organ size per se received less selection pressure than when the oMt1a-oGH transgene was not present.

\section{Activated transgene plus selection versus selection alone}

The presence of the activated oMt1a-oGH transgene and selection combined had a greater impact on increasing the size of the liver, spleen and kidney than did selection for increased 8-week body weight alone. We have already shown that the presence of the inactivated GH transgene has reduced the genetic correlation between organ weights and body weight. Therefore, it seems that the activated oGH transgene has a much larger effect on increasing the size of liver, spleen and kidney than does selection for growth rate. A distinction between the effects of selection for increased growth and the activated oMt1a-oGH transgene is that splanchnomegalic organ weights as a percentage of body weight approach those of nontransgenic controls with an increased period of transgenic inactivation (Sharp et al., 1995). Another difference is the pathomorphological findings for liver, kidney and heart in chronically expressed GH transgenic mice (reviewed by Wanke et al., 1996).

\section{GH transgene in livestock breeding}

Siewerdt et al. $(1999,2000)$ have shown with a mouse model that combining conventional selection for increased growth with a regulated $\mathrm{GH}$ transgene is feasible provided 
extreme selection for growth rate had not occurred previously and the gene construct has no major fitness flaws. Previous studies have indicated that selection for greater growth will increase visceral organ size to meet metabolic demands of a larger muscle mass, thus increasing maintenance requirements. The present results suggest that the activated $\mathrm{GH}$ transgene may lead to a proportionally greater increase in visceral organ size, particularly the liver and spleen, than selection for increased growth rate. The distinction is that by being able to inactivate the $\mathrm{GH}$ transgene, organomegaly and hepatic lesions can be resolved (Sharp et al., 1995). The challenge will be to construct transgenes for livestock having the desirable features of being regulated, having no detrimental fitness effects and no pathological effects.

\section{ACKNOWLEDGMENTS}

Research supported by USDA National Research Initiative Competitive Grant No. 9403975 and the North Carolina Agriculture Research Service (NCARS), Raleigh, NC 27695-7643, USA. The use of trade names in this publication does not imply endorsement by the NCARS, nor criticism of similar ones not mentioned.

\section{RESUMO}

O objetivo do presente estudo foi comparar as respostas correlacionadas no peso absoluto do fígado, baço, rim, coração e testículo e como uma percentagem do peso corporal em 8 semanas após seleção para grande peso corporal de 8 semanas em linhagens de camundongos não transgênicos e portadores de transgene replicado duas vezes, originados de dois backgrounds genéticos. O transgene era um composto de hormônio de crescimento ovino metalotioneína 1a-ovino (oMt1a-oGH), que foi ativado pela adição de $25 \mathrm{mM} \mathrm{ZnSO}_{4}$ à água de beber. Linhagens $\mathrm{MM}$ e $\mathrm{NC}$ eram linhagens não transgênicas derivadas de background de alto crescimento e selecionado ao acaso, respectivamente. As linhagens TM e TC eram portadoras de transgene formadas a partir dos respectivos backgrounds genéticos. A linhagem CC era um controle não transgênico obtido de background selecionado ao acaso. No desmame, os camundongos machos de cada linhagem foram alocados para água de beber com suplemento de zinco ou controle. Clips de dedos foram testados por PCR para detectar a presença ou não do transgene. As respostas correlacionadas dos pesos absolutos de todos os órgãos nas linhagens não transgênicas indicaram correlações genéticas moderadamente elevadas dos pesos dos órgãos com o peso corporal, mas com relação à porcentagem do peso corporal, as respostas correlacionadas foram muito menores. As respostas correlacionadas nos pesos das vísceras foram menores na presença do transgene oMt1a-oGH inativado do que na sua ausência. A presença do oMt1a-oGH ativado combinada com os efeitos da seleção para aumento do crescimento tiveram um impacto maior no aumento do peso dos órgãos esplâncnicos do que a seleção para peso corporal elevado na ausência do transgene.

\section{REFERENCES}

Brem, G. and Wanke, R. (1988). Phenotypic and pathomorphological characteristics in a halfsib-family of transgenic mice carrying MT-hGH genes. In: New Developments in Bioscience: Their Implications for Laboratory Animal Science (Beynen, A.C. and Solleveld, H.A., eds.). Martinus Nijhoff Publ., Dordrecht, 93-98.

Brem, G., Wolf, E., Buchmüller, T., Müller, M., Brennig, B. and Hermanns, W. (1989). Multiple consequences of human growth hormone expression in transgenic mice. Mol. Biol. Med. 6: 531-547.

Bünger, L., Remus, N. and Roschlau, D. (1985). Selection for different growth parameters in laboratory mice and its correlated effects on body composition and organ weights. Nahrung 29: 549-560.

Cecim, M., Bartke, A., Yun, J.G. and Wagner, T.A. (1993). Growth allometry of transgenic mice expressing the mouse metallothionein-I bovine/growth hormone gene. Transgene 1: 125-132.

Clutter, A.C. and Brascamp, E.W. (1998). Genetics of performance traits. In: The Genetics of the Pig (Rothschild, M.F. and Ruvinsky, A., eds.). CABI Publishing, Oxon, 427-462.

Eisen, E.J. (1966). Effect of the biometrical relationship among total milk yield, milk constituent yield, and per cent of milk constituent on response to selection. J. Dairy Sci. 49: 1230-1234.

Eisen, E.J. (1975). Population size and selection intensity effects on longterm selection response in mice. Genetics 79: 305-323.

Eisen, E.J. (1986). Maturing patterns of organ weights in mice selected for rapid postweaning gain. Theor. Appl. Genet. 73: 148-157.

Eisen, E.J. and Johnson, B.H. (1981). Correlated responses in males reproductive traits in mice selected for litter size and body weight. Genetics 99: 513-524

Eisen, E.J., Hayes, J.F., Allen, C.E., Bakker, H. and Nagai, J. (1978). Cellular characteristics of gonadal fat pads, livers and kidneys in two strains of mice selected for rapid growth. Growth 42: 7-25.

Eisen, E.J., Murray, J.D. and Schmitt, T.J. (1995). An ovine growth hormone transgene model suitable for selection experiments for growth in mice. J. Anim. Breed Genet. 112: 401-413.

Falconer, D.S., Gauld, I.K. and Roberts, R.C. (1978). Cell numbers and cell sizes in organs of mice selected for large and small size. Genet. Res. 31:287-301.

Garlick, P.J., Burk, G.L. and Swick, R.W. (1976). Protein synthesis and RNA in tissues of the pig. Am. J. Physiol. 230: 1108-1112

Kramer, M.G., Vaughn, T.T., Pletscher, L.S., King-Ellison, K., Adams, E., Erikson, C. and Cheverud, J.M. (1998). Genetic variation in body weight gain and composition in the intercross of large (LG/J) and small (SM/J) inbred strains of mice. Genet. Mol. Biol. 21: 211-218.

Littell, R.C., Milliken, G.A., Stroup, W.W. and Wolfinger, R.D. (1996). SAS ${ }^{\circledast}$ System for Mixed Models. SAS Inst. Inc., Cary.

Mrode, R.A. (1988). Selection experiments in beef cattle. Part 2: A review of responses and correlated responses. Anim. Breed Abst. 56: 155167.

Nagai, J., Lin, C.Y. and Saber, P. (1993). Selection for increased adult body weight in mouse lines with and without the rat growth hormone transgene. J. Anim. Breed. Genet. 110: 371-384.

Nash, D.J. and Logsdon Jr., D.F. (1978). Morphological and physiologica changes in mice (Mus musculus) selected for large size. Comp. Biochem. Physiol. A61: 283-285.

Parks, K.R., Eisen, E.J., Parker, I.J., Hester, L.G. and Murray, J.D. (2000a). Correlated responses to selection for large body size in oMt1a-oGH transgenic mice: reproductive traits. Genet. Res.75: 199-208.

Parks, K.R., Eisen, E.J. and Murray, J.D. (2000b). Correlated responses to selection for large body size in oMt1a-oGH mice: growth, feed efficiency and body composition. J. Anim. Breed Genet. 117: 385-405.

Pinkert, C.A. and Murray, J.D. (1999). Transgenic farm animals. In: Transgenic Animals in Agriculture (Murray, J.D., Anderson, G.B., Oberbauer, A.M. and McGloughlin, M.M., eds.). CABI Publishing, Oxon, 1-18.

Pomp, D. and Murray, J.D. (1991). Single day detection of transgenic mice by PCR of toe-clips. Mouse Genome 89: 279.

Pomp, D., Nancarrow, C.D., Ward, K.A. and Murray, J.D. (1992). Growth, feed efficiency and body composition of transgenic mice expressing a sheep metallothionein 1a-sheep growth hormone fusion gene. Livest. Prod Sci. 31: 335-350.

Pursel, V.G., Wall, R.J., Mitchell, A.D., Elasser, T.H., Solomon, M.B., Coleman, M.E., DeMayo, F. and Schwartz, R.J. (1999). Expression of insulin-like growth factor-I in skeletal muscle of transgenic swine. In: Transgenic Animals in Agriculture (Murray, J.D., Anderson, G.B., 
Oberbauer, A.M. and McGloughlin, M.M., eds.). CABI Publishing, Oxon, 131-144.

Robinson, D.W. and Bradford, G.E. (1969). Cellular response to selection for rapid growth in mice. Growth 33: 221-229.

Shanahan, C.M., Rigby, N.W., Murray, J.D., Marshall, J.T., Townrow, C.A., Nancarrow, C.D. and Ward, K.A. (1989). Regulation of expression of a sheep metallothionein 1a-sheep growth hormone fusion gene in transgenic mice. Mol. Cell. Biol. 9: 5473-5479.

Sharp, K.R., Knudson, D.E.B., Pomp, D. and Murray, J.D. (1995). Expression of an ovine growth hormone transgene in mice causes organomegaly and hepatic lesions which resolve following transgene inactivation. Lab. Anim. Sci. 45: 607-612.

Shea, B.T., Hammer, R.E. and Brinster, R.L. (1987). Growth allometry of the organs in giant transgenic mice. Endocrinology 121: 1924-1930.

Siewerdt, F., Eisen, E.J., Conrad-Brink, J.S. and Murray, J.D. (1998) Gene action of the oMt1a-oGH transgene in two lines of mice with distinct selective backgrounds. J. Anim. Breed Genet. 115: 211-226.

Siewerdt, F., Eisen, E.J. and Murray, J.D. (1999). Direct and correlated responses to short-term selection for 8-week body weight in lines of transgenic (oMt1a-oGH) mice. In: Transgenic Animals in Agriculture (Murray, J.D., Anderson, G.B., Oberbauer, A.M and McGloughlin, M.M., eds.). CABI Publishing, Oxon, 231-250.

Siewerdt, F., Eisen, E.J., Murray, J.D. and Parker, I.J. (2000). Response to 13 generations of selection for increased 8-week body weight in lines of mice selected for increased 8-week body weight. J. Anim. Sci. 78: $832-845$

Simm, G. (1992). Selection for lean meat production in sheep. In: Recent Advances in Sheep and Goat Research (Speedy, A.W., ed.). CABI Publishing, Oxon, 193-215.

Taylor, St. C.S. (1980). Genetic size-scaling rules in animal growth. Anim. Prod 30: 161-165.

Tess, M.W., Dickerson, G.E., Nienaber, J.A. and Ferrell, C.L. (1984). The effects of body composition on fasting heat production in pigs. $J$. Anim. Sci. 58: 99-110.

Wanke, R., Wolf, E., Hermanns, W., Folger, S., Buchmüller, T. and Brem, G. (1992). The GH-transgenic mouse as an experimental model for growth research: clinical and pathological studies. Horm. Res. 37 (Suppl. 3): 74-87.

Wanke, R., Wolf, E., Brem, G. and Hermanns, W. (1996). Physiology and pathology of growth - studies in GH transgenic mice. J. Anim. Breed. Genet. 113: 445-456.

(Received July 14, 2000) 